\title{
Glossite rombóide mediana associada a candidíase esofagiana. Uma possível relação etiológica com a Candida albicans*
}

\section{Median rhomboid glossitis associated with esophagic candidiasis. A possible etiologic relation with candida albicans*}

\author{
Dr. Rubens Marcelo Souza Leite ${ }^{l}$ \\ Dr. Horácio Friedman ${ }^{3}$
}

\author{
Dra. Adriana Aragão Craveiro Leite ${ }^{2}$ \\ Dra Isabel Friedman ${ }^{4}$
}

\begin{abstract}
Resumo: A glossite rombóide mediana é doença inflamatória que ocorre na superfície da língua. Apresentase como placa avermelhada ou vermelho-esbranquiçada no dorso da língua, na localização mediana. A etiologia é desconhecida. Acredita-se que possa haver relação com a má formação dos arcos branquiais durante a embriogênese. Fatores infecciosos relacionados à Candida albicans também são aventados.

Os autores apresentam o caso clínico de uma paciente de 60 anos, com glossite rombóide mediana associada a esofagite candidiásica, ambas responsivas ao tratamento com itraconazol e fluconazol oral. Discutese se a cândida não seria um dos fatores implicados na etiologia da doença lingual.

Palavras-chave: Etiologia; glossite.
\end{abstract}

Summary: Median rbomboid glossitis is an inflammatory disease involving the surface of the tongue. It develops clinically as an erythematous or white-erythematous area on the dorsal median surface of the tongue. Etiologic factors are unknown. One of the possible etiologic theories suggests a relation between median rhomboid glossitis and malformation of bronchial arches during embriogenesis. Candida albicans as an infectious etiologic factor has also been suggested.

The study presents the case of a 60-year-old patient with median rbomboid glossitis associated with esophagic candidiasis. Both pathologies responded well to therapy with oral itraconazole and fluconazole. The authors argue in favor of the possibility of an etiologic relation between Candida albicans and median rbomboid glossitis

Key words: Etiology; glossitis.

\footnotetext{
Recebido em 23.04.2000. / Received in April, $23^{\text {th }}$ of 2000.

Aprovado pelo Conselho Consultivo e aceito para publicação em 13.03.2002. / Approved by the Consultive Council and accepted for publication in March, $13^{\text {th }}$ of 2002. * Trabalho Realizado no Serviço de Dermatologia do Setor de Clínica do Departamento Médico da Câmara dos Deputados - Brasília-DF. / Work done at "Serviço de Dermatologia do Setor de Clínica do Departamento Médico da Câmara dos Deputados - Brasília-DF".

Dermatologista do Departamento /Médico da Câmara dos Deputados - Brasília-DF. / Dermatologist of the Federal House of Representatives Medical Department Brasilia- $D F$.

Alergista e imunologista pediátrica do Serviço de Saúde do Supremo Tribunal Federal - Brasília-DF. / Pediatric allergist and immunologist of the Federal Supreme Court Health Service - Brasilia-DF.

${ }^{3}$ Patologista do laboratório diagnose de Brasília e professor de patologia da Universidade de Brasília - Brasília-DF. / Pathologist of the Brasilia Diagnosis Laboratory and Professor of Pathology at the Universidade de Brasilia - Brasilia-DF.

${ }^{4}$ Patologista do laboratório diagnose de Brasília- Brasília-DF. / Pathologist of the Brasilia Diagnosis Laboratory - Brasilia-DF. 


\section{INTRODUÇÃO}

A glossite rombóide mediana (GRM) é doença inflamatória que ocorre no dorso da língua. Apesar de benigna, ela pode ser confundida com processos graves pelo paciente ou por um observador inexperiente. A apresentação clínica mais comum da doença é uma vermelhidão ou um vermelho-esbranquiçado na parte mediana do dorso da língua, imediatamente anterior à região do $\mathrm{V}$ da papila circunvalada (sulco terminal). A região avermelhada da mucosa pode ser plana ou elevada. Ela é normalmente bem circunscrita, com formato rombóide, e lisa. Ocasionalmente, existe um componente nodular ou o órgão pode estar lobulado. A textura pode ser similar à língua subjacente ou firme, e a superfície é relativamente macia. ${ }^{1}$ Às vezes é observada a candidíase do palato, mais comumente em pacientes imunodeprimidos. Os fatores causadores da doença são desconhecidos.

Os autores relatam o caso de uma paciente com GRM, cujo quadro clínico e evolução sugerem Candida albicans como agente etiológico.

A doença é relativamente rara, e o que suscita mais dúvidas em relação à mesma é o tema referente a sua etiologia. Defendem a idéia de a etiologia do processo estar relacionada à infecção pela Candida albicans, com base no caso clínico descrito com a presença de infecção candidiásica contígua esofagiana e na resposta terapêutica a antifúngicos.

\section{RELATO DO CASO}

Paciente do sexo feminino, 60 anos, fumante, procedente de Tocantins, procurou o serviço com história clínica de um ano e seis meses de evolução de uma "mancha na língua", com sensação de ardor ao se alimentar, sobretudo na ingestão de alimentos ácidos e condimentos. Recentemente a paciente havia referido disfagia com alimentos sólidos e líquidos, tendo sido então examinada por odontólogos e dermatologistas, que julgaram ser a doença de natureza alérgica. Dietas, corticóides locais e tretinoína tópica não acarretaram melhora clínica. Não havia relato de doenças cutâneas ou mucosas anteriores nem de doenças sistêmicas.

Ao exame físico geral observava-se paciente em bom estado, sem déficit nutricional, normocorada, hidratada. O exame da orofaringe demonstrava dentição sem alterações significativas e uma área avermelhada, lisa, circunscrita, sem as papilas gustativas, na região central da língua (Figura 1). Não havia outras alterações bucais ou da pele.

O hemograma revelava série vermelha normal e leucócitos com contagem e diferenciais normais; a glicemia era normal, a função tireoidiana, inalterada, e uréia, creatinina e transaminases, normais. Urinálise e exame de fezes sem alterações.

Foi realizada biópsia da língua, cujo exame histológico mostrou epitélio malpighiano com pobreza de papilas, paraqueratose, atenuação da camada granulosa, acantose, alongamento das cristas, exocitose de mononucleares, e

\section{INTRODUCTION}

Median rhomboid glossitis (MRG) is an inflammatory disease occurring on the dorsal surface of the tongue. As well as being benign, it can be mistaken as serious processes by the patient or an inexperienced observer. The most common clinical presentation of the disease is an erythematous or white- erythematous area on the dorsal median surface of the tongue, immediately prior to Region $V$ of the circumvallate papilla (terminal gingiva). The erythematous region of the mucose can be flat or raised. It is normally well circumscribed, with a rhomboid shape, and smooth. A nodular component is occasionally found, or the organ can be lobulated. The texture may be similar to the subjacent or firm part of the tongue, and its surface is relatively soft. ${ }^{1}$ At times, candidiasis of the palate is observed, but this is more common in immunodepressive patients. Causative factors are unknown.

The authors report the case of a patient with $M R G$, whose clinical form and course suggest Candida albicans as an etiological agent.

The disease is relatively rare, but what raises more doubts with respect to it is its referent theme to its etiology. We argue that the etiology of the process is related to infection by Candida albicans on the basis of the clinical case described. This shows the presence of candidiasic infection contiguous to the esophagus and in the therapeutic response to antifungal agents.

\section{CASE REPORT}

A 60-year-old female patient, a smoker, resident of Tocantins, sought help with a year-and-six-month long clinical history in the evolution of a "spot on the tongue". She experienced difficulty in eating, especially when ingesting acidic foods and condiments. Recently, the patient referred to dysphagia with solid foods and liquids, was then examined by dentists and dematologists, who judged it to be an illness of an allergic nature. Diets, local corticoids and topical tretinoin did not trigger clinical improvement. There was no report of an antecedent cutaneous or mucose illness, nor of systemic diseases.

During the general physical examination the patient was observed to be in a good state, without nutritional deficit, normal colored and hydrated. The examination of the oropharinx showed no significant alteration to dentition, and a smooth, circumscribed erythematous area, without the taste buds, in the central region of the tongue (Figure 1). There were no other buccal or dermic alterations.

The blood-cell count revealed a normal red-blood cell series and a normal count and differential for leukocytes; glucose was normal, the thyroid function unaltered, and urea, creatine and transaminases, all normal. Urine analysis and feces examination had no alterations.

A biopsy of the tongue was performed, whose histological examination showed Malpighian epithelial with few papillae, parakeratosis, atenuation of the granulous layer, acanthosis, elongating of the edges, mononuclear exocyto- 


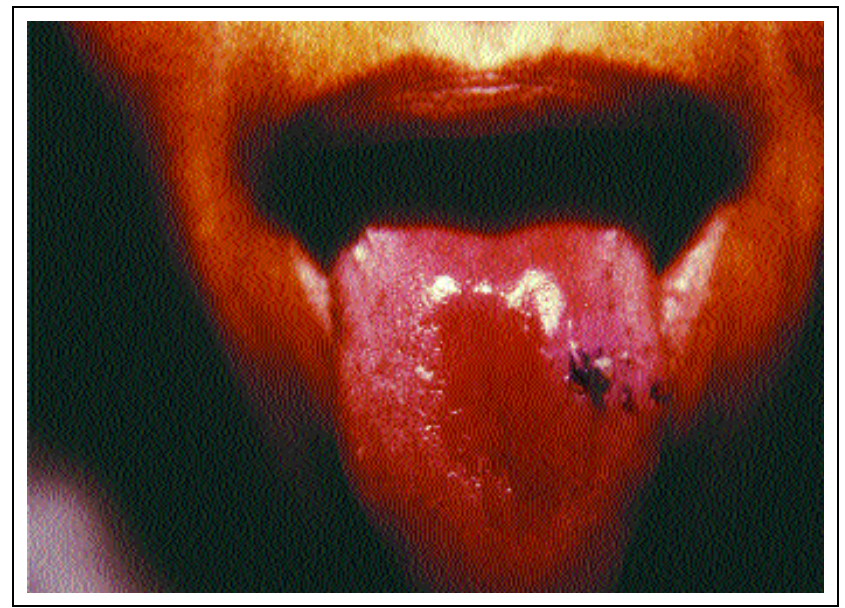

Figura 1: Área avermelhada, lisa, circunscrita, com ausência de papilas gustativas, na região central da língua

Figure 1: Erythematous area, smooth, circumscribed, with absence of taste buds, in the central region of the tongue.

escassos neutrófilos. No cório foram observados vasos congestos e discreto infiltrado mononuclear intersticial (Figura 2).

O diagnóstico de GRM foi então sugerido. A endoscopia digestiva alta revelou exsudato esbranquiçado, removido parcialmente por lavagem, ocupando toda a extensão do esôfago (figura 3), além de pangastrite e uma úlcera duodenal. A cultura do exsudato removido das paredes esofagianas revelou Candida albicans. A paciente foi rastreada com ultra-sonografia e tomografia computadorizada para neoplasias ou doenças associadas, sem outros achados. Investigação para imunodeficiências foi negativa para HIV. Testes cutâneos de leitura tardia foram realizados, com PPD positivo com medição de $7 \mathrm{~mm}$, e teste de candidina positivo com medição de $9 \mathrm{~mm}$.

A paciente foi submetida a tratamento com itraconazol 100mg VO/dia por 30 dias, com remissão total do quadro esofagiano e concomitante desaparecimento das lesões linguais. Retornou três meses depois com queixas de recidiva do quadro lingual. Foi prescrito, então, fluconazol $150 \mathrm{mg} \mathrm{VO} / \mathrm{semana}$ por quatro semanas, com nova remissão. Ao final de quatro meses, a paciente retornou com o reaparecimento do quadro clínico. Os autores optaram por reintroduzir o fluconazol 150mg VO/semana, com desaparecimento das lesões. Desde então, tem sido mantida uma dose mensal de

Figura 3: Endoscopia digestiva alta com exsudato esbranquiçado por Candida albicans em toda a extensão do esôfago

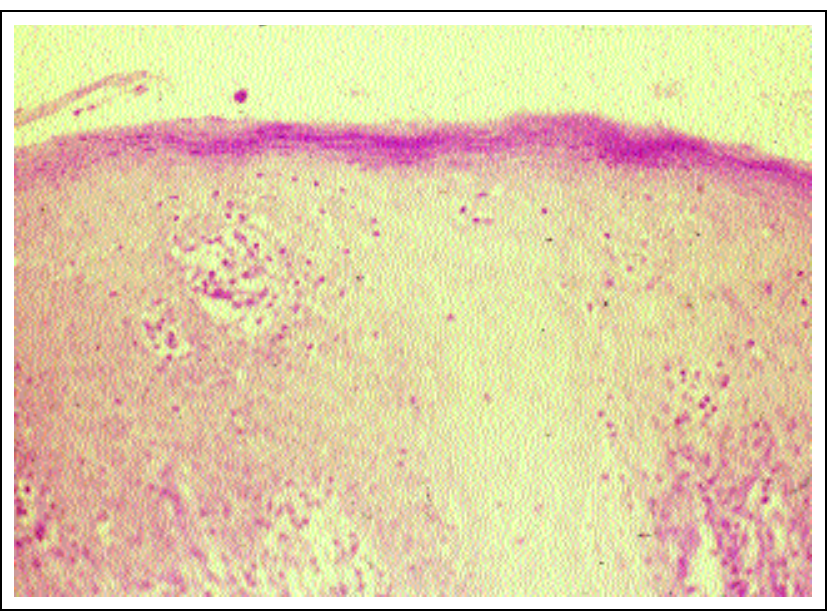

Figura 2: Histopatologia da lesão da língua. HE 40x Figure 2: Histopatology of the tongue lesion. HE $40 x$

sis and few neutrophils. In the dermis, congested vessels and discreet inflitrated mononuclear interstices were observed (Figure 2).

Diagnosis of MRG was then suggested. The high digestive endoscopy revealed whitish exsudate, partially removed by washing, which took up the whole extension of the esophagus (figure 3), except for the pangastritis and a duodenal ulcer. The culture of the removed exsudate of the esophagus walls revealed Candida albicans. The patient was scanned with ultra-sonograph and computed tomography for neoplasias or associated diseases, without other findings.

Investigation for immunodeficiencies was negative for HIV. Late reading cutaneous tests of late reading were performed, $P P D$ positive measuring $7 \mathrm{~mm}$, and the candidiasis test was positive measuring $9 \mathrm{~mm}$.

The patient was subjected to treatment with itraconazol 100mg VO/day for 30 days, with total remission of the esophagous disorder and concomitant disappearance of the tongue lesions. The conditions returned three months later with complaints of relapsing of the tongue lesions. Fluconazol $150 \mathrm{mg}$ VO/week was then prescribed for four weeks, with new remission. At the end of four months, the patient returned with the reappearance of the clinical form. The authors opted to reintroduce the $150 \mathrm{mg}$ VO/week fluconazol, resulting in the disappearance of lesions. Since then, a monthly dose of 150mg VO

Figure 3: High digestive endoscopy with whitish exsudate for Candida albicans over the whole extension of the esophagus. 
fluconazol $150 \mathrm{mg}$ VO, permanecendo a paciente até o momento sem recidiva.

\section{DISCUSSÃO}

A GRM é um problema estomatológico incomum. A prevalência em adultos é de menos de $1 \%$. A idade média de seu surgimento varia entre os 40 e os 45 anos. Os fatores que contribuem são dentes inclusos, uso de antibióticos, tabagismo e ocasionalmente defeitos imunológicos. ${ }^{1} \mathrm{Um}$ estudo realizado com mais de 10.000 estudantes não foi capaz de detectar um único caso da doença, e não existem casos descritos em recém-nascidos. ${ }^{2}$

A doença é normalmente assintomática, podendo causar sensação de queimação associada a alimentos condimentados, o que levou a paciente descrita a procurar auxílio médico. A etiologia é desconhecida, apesar de no passado a GRM ter sido considerada uma falha no desenvolvimento dos arcos branquiais, com a persistência do tuberculum impar. ${ }^{2.3}$ Outros autores defendem a idéia de que a pressão da língua em contato com o palato ao produzir sons como $g, k$ e $j$, e o atrito produzido pela língua ao engolir produziriam excessiva pressão, justificando o desnudamento das papilas naquela região e a conseqüente nodosidade, ocasionalmente observada na GRM. ${ }^{5}$

Nos últimos 20 anos, evidências da presença de Candida albicans na lesões demonstraram uma associação patogênica mais provável. ${ }^{3,4,67,7}$ Arendorf \& Walker sugeriram que a língua é um reservatório primário para a cândida e postularam que a grande área das papilas linguais serviriam como abrigo para esses fungos. ${ }^{9}$ Além disso, a grande concentração desses organismos na região mediana da língua poderia explicar a gênese da GRM. Whitaker refere que a posição da região mediana da língua em estreito contato com o palato torna essa região menos propensa ao clearence salivar e que é nessa área que as alterações acontecem na GRM. ${ }^{10}$ $\mathrm{O}$ mesmo autor registra que o dorso da língua contém mais fissuras e dobras, facilitando o crescimento de cândida. Sabese que $44 \%$ da população tem cândida como parte da sua flora bucal normal. Na maioria dos casos, a cândida pode ser isolada em cultura do material obtido das lesões e o exame histológico revela hifas penetrando o epitélio superficial da língua, com microabscessos neutrofílicos. ${ }^{7}$ Em geral, a GRM é um achado em muitos pacientes e pode não ser diagnosticada. A realização da biópsia deve ser indicada, já que muitas lesões são nodulares e podem simular uma neoplasia.

$\mathrm{O}$ caso em questão demonstra que a cândida pode ser um dos fatores ou o agente etiológico principal no desenvolvimento da GRM. O desaparecimento da GRM em três tratamentos subseqüentes com antifúngicos orais, além de sua concomitância com a presença de candidíase esofagiana, reforça a participação da cândida como fator ou um dos fatores na gênese da alteração lingual na paciente. fluconazol has been administered, the patient until this time has had no reincidence of the clinical form.

\section{DISCUSSION}

$M R G$ is an uncommon stomatological problem. Prevalence in adults is less than 1\%. Emergence appears in patients with an average age of 40 to 45 years. Contributing factors are unerupted teeth, use of antibiotics, smoking and occasional immunological defects. ${ }^{I}$ A study performed on more than 10,000 students was unable to detect a single case of the disease, and there are no cases described among newborns. ${ }^{2}$

The disease is normally asymptomatic, able to cause a burning sensation associated with food condiments, which led the patient in question to seek an medical assistance. Etiology is unknown, however in the past MRG was considered a developmental malformation of the bronchial arches, with persistence of tuberculum impar. ${ }^{2,3}$ Other authors have upheld the idea that tongue pressure in contact with the palate when producing sounds like $\mathrm{g}, \mathrm{k}$ and $\mathrm{j}$, and the friction produced by the tongue when swallowing exerts excessive pressure, justifying the stripping of the papillae in the region and the consequent formation of nodes, as occasionally observed in $M R G$.

In the last 20 years, evidence of the presence of Candida albicans in the lesions shows a more probable pathogenetic association. ${ }^{3,46,7,8}$ Arendorf and Walker have suggested that the tongue is a primary reservoir for candidiasis and postulated that the large area of tongue papillae serve as shelter for these fungi. ${ }^{9}$ This being said, the large concentration of these organisms in the median region of the tongue in direct contact with the palate makes this region less propitious to salivary clearance, and it is in this area that alterations occur in the $M R G .^{10}$ The same authors have recorded that the dorsal region of the tongue contains more fissures and folds, facilitating the growth of candidiasis. It is known that $44 \%$ of the population has candidiasis as part of its normal buccal flora. In most cases, candida can be isolated in material culture obtained from the lesions. The histological examination reveals hyphae penetrating the epithelial surface of the tongue with neutrophilic microabsesses. ' In general, MRG has to be found in many patients and cannot be diagnosed. The performing of a biopsy should be recommended, given that many lesions are nodular and can simulate a neoplasia. The case in question demonstrates that candidiasis can be one of the factors or principal etiological agents in the development of $M R G$. The disappearance of $M R G$ in three subsequent oral antifungus treatments, apart from being concomitant to the presence of esophagic candidiasis, reinforces the participation of candidiasis as a factor, or one of the factors, in the genesis of tongue alteration in the patient. 


\section{REFERÊNCIAS / REFERENCES}

1. Holmstrup P, Besserman M. Clinical, therapeutic, and pathogenic aspects of chronic oral multifocal candidiasis. Oral Surg Oral Med Oral Pathol 1983; 56:388-95.

2. Baughman RA. Median rhomboid glossitis: a developmental anomaly? Oral Surg Oral Med Oral Pathol 1971;31:56-65.

3. Wright BA. Median rhomboid glossitis: not a misnomer. Review of the literature and histologic study of twenty-eight cases? Oral Surg Oral Med Oral Pathol 1978;46:806-14.

4. Van der Waan Y, Beemster G, Van der Kwast WAM. Median rhomboid glossitis caused by candida.? Oral Surg Oral Med Oral Pathol 1979;47:31-35.

5. Kessler HP. Median rhomboid glossitis. Oral Surg Oral Med Oral Pathol 1996;82:360.
6. Cooke BED . Median rhomboid glossitis: candidiasis and not a developmental anormaly. Br J Dermatol. 1975;93:399-405.

7. Touyz LZ, Peters E. Candida infection of the tongue with no nonespecific inflammation of the palate. Oral Surg Oral Med Oral Pathol 1987;63:304-08.

8. Van der Waan N. Candida albicans in median rhomboid glossitis: a post-mortem study. Int $\mathbf{J}$ Oral Maxillofac Surg 1986; 15:322-25.

9. Arendorf TM, Walker DM. The prevalence and intraoral distribution of Candida albicans in man. Arch Oral Biol 1980;25:1-1. 10. Whitaker SB. Causes of median rhomboid glossitis. Oral Surg Oral Med Oral Pathol 1996;81:379-80.

ENDEREÇO PARA CORRESPONDÊNCIA: / MAILING ADDRESS: Rubens Marcelo Souza Leite SMHN Q 2, Edifício de Clínicas, Sala 108, Brasília DF 70710-906

Telefone: (61)3278482, Fax (61) 3277576

E-mail: dermatologia@dr.com 